\title{
PASADO, PRESENTE Y FUTURO \\ DE LOS DIAGNÓSTICOS DE ENFERMERÍA
}

\author{
Marjory Gordon (R.N., Ph.D., F.A.A.N.)
}

\section{RESUMEN}

Con este trabajo la autora pretende crear una línea de discusión acerca del Pasado, Presente y Futuro de los Diagnósticos de Enfermería contextualizando el término desde dos perspectivas distintas: como una "categoría" y por otro lado como un "proceso". En el desarrollo del artículo se muestran los hechos que han ido sentando las bases para el desarrollo de los Diagnósticos de Enfermería dentro de la práctica clínica.

Palabras clave: Diagnósticos de enfermeria

\section{NURSING DIAGNOSIS: PAST, PRESENT, FUTURE}

In this paper I would like to discuss the Past, Present, and Future of the nursing diagnosis, as a category and as a process. There were a series of events that set the stage for the development of nursing diagnoses and a focus on nurses clinical reasoning skills.

Keywords: Nursing diagnosis

El término diagnóstico de Enfermería hace referencia no sólo a una categoría sino también a un proceso. Cuando hablamos de diagnóstico de Enfermería como una categoría, lo hacemos para referirnos a un juicio diagnóstico. En los últimos 26 años, se han identificado aproximadamente 158 categorías diagnósticas gracias a la NANDA (Asociación Norteamericana de Diagnósticos de Enfermería), además de muchas otras ya existentes en la Clasificación Internacional para la práctica de la Enfermería. Cada una de estas categorías diagnósticas debe ser sometida a una revisión que examine con detenimiento su sensibilidad cultural. Sin embargo, cuando nos referimos al término diagnóstico de Enfermería en relación a un proceso, lo hacemos con la intención de mostrar el proceso de razonamiento y juicio clínico que nos llevará a la creación del diagnóstico en sí.

En este trabajo me gustaría hablar acerca del Pasado, presente y futuro de los diagnósticos de Enfermería, como una categoría y como un proceso. De hecho, se han dado a lo largo de la historia una serie de acontecimientos que fueron cruciales para el desarrollo de estos diagnósticos y de las habilidades para el razonamiento clínico de las enfermeras/os.

\section{TRANSICIONES DEL PASADO AL PRESENTE:}

Me gustaría sugerir que la práctica enfermera ha experimentado cambios drásticos en todo el mundo a partir de la segunda mitad del siglo XX. Los historiadores han interpretado estos cambios como signos de una revolución cultural o profesional, mientras que para otros ha significado un cambio paradigmático. El aspecto central explicativo de todos estos cambios es el hecho de que las enfermeras reconocen que ellas mismas hacen juicios clínicos paralelamente a aquellos que están asociados directamente con la enfermedad o patología, es decir, los juicios médicos. Los profesionales de Enfermería llevan a cabo actividades en relación a esos juicios propios y en el proceso de desarrollo del diagnóstico de Enfermería aumenta la calidad de la salud de la comunidad o grupo sobre el que se actúa. 
Las enfermeras/os día a día desarrollan un lenguaje específico para comunicar estos juicios que determinan sus diagnósticos, sus intervenciones y resultados. Este cambio ha enfatizado la importancia de la atención enfermera y ha hecho hincapié en el tipo de información que la enfermera/o recoge para su diagnóstico, plan de cuidados y evaluación. El interés puesto en la atención integral de Enfermería y particularmente en los patrones funcionales de salud nos lleva a determinar que los diagnósticos realizados por las enfermeras/os nos parecerán lo suficientemente válidos siempre que la atención prestada al paciente produzca una información, a su vez, válida y de confianza. A continuación consideraremos algunos de los momentos de transición que han originado nuevas formas de práctica enfermera en todo el mundo.

Desde hace 25 años las enfermeras vienen dándose cuenta de la importancia de los juicios clí- nicos que ellas mismas producen para identificar y clasificar las características de aquello con lo que tratan, es decir, existe la necesidad de dar un nombre a las actividades que mejor responden a la intervención que lleva a cabo Enfermería. Este reconocimiento por parte del colectivo enfermero ha sido el que ha cambiado totalmente la práctica de la Enfermería en muchos países. De hecho, se ha dado un momento de transición en relación con la forma de hablar y expresarse dentro del desarrollo de nuestra práctica y de nuestra forma de pensar como enfermeras/os.

Por ejemplo, actualmente en vez de precipitarnos en el momento de hacer conjeturas sobre el aspecto emocional del paciente, somos más precisos a la hora de crear un diagnóstico diferencial entre miedo y ansiedad. En vez de decir que un paciente necesita que se le enseñe sobre... o que debe aprender esto o aquello..., ahora diag-

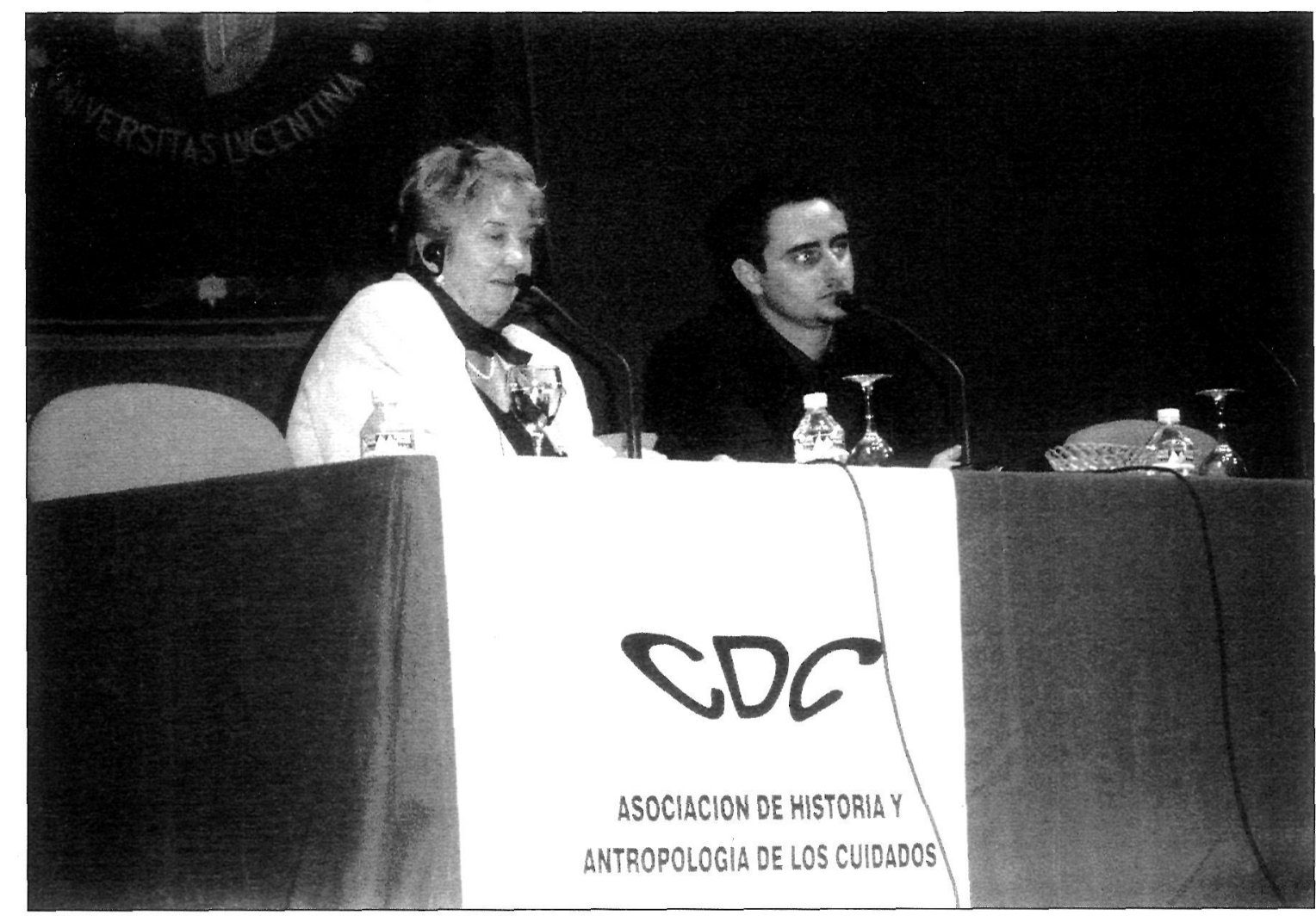


nosticamos un déficit de conocimientos o un problema motivacional; incluso podríamos hablar de un conflicto cultural en relación al tratamiento prescrito. Así, algunos pacientes precisan de cierta educación de la salud en determinados temas y otros no; y esto podría estar relacionado con otro problema latente tal como el de la abnegación o falta de motivación. Cuando la enfermera juzga que el paciente tiene una ventilación inefectiva, muchas posibilidades le vienen a la mente, tales como: ipor qué el paciente tiene ese problema?, ¿podria deberse a secreciones espesas por falta de fluídos?, ¿podría deberse a una tos no productiva?, ¿ipuede que precise la aspiración de secreciones? Por su puesto, todas estas y otras más vienen a la mente de la enfermera.

Puede que algunos de los lectores no crean lo que contaré a continuación, pero en el área de juicio clínico, las enfermeras solían aprender a decir: parece que... está sangrando. Afortunadamente hoy por hoy los juicios diagnósticos, terapéuticos y éticos se incluyen dentro del rol profesional de la enfermera. Otro ejemplo como el anterior sería: parece que... ha fallecido. ¡Realmente ha sido un gran paso el que ha dado la Enfermería!

El Consejo Internacional de Enfermeras en Ginebra (ICN) ha apoyado durante años la iniciativa de un equipo que ha servido de impulsor en la creación de una clasificación útil en la práctica enfermera. Los miembros y participantes en este equipo provienen de Dinamarca, Inglaterra $y$ EEUU. El proyecto se ha llamado: El Próximo Avance de la Enfermería. Este equipo actualmente trabaja en la creación de una clasificación internacional que tenga la función de describir y clasificar los diagnósticos, actividades y resultados de la práctica enfermera. Después de la creación del primer informe en 1993, se publicó una versión del sistema de clasificación, denominada versión alfa, así como otro boletín denominado versión beta, que se encuentra en la web de la ICN (http://www.nethotel.dk/dihnr/Telenurse/ICNP/beta).
La Clasificación Internacional para la Práctica Enfermera no estuvo basada en ningún modelo conceptual, probablemente debido al pluralismo teórico (término empleado por James \& Dickoff en los años 70, para describir la coexistencia de muchas teorías sobre Enfermería tales como la del autocuidado, adaptación, patrones vitales, y otras...) existente en la mayoría de los países donde se practica una Enfermería profesional.

Los diagnósticos dentro de la clasificación de la ICN se ordenan en relación a los fenómenos causantes. Los resultados se definen como el estado en que se encuentra el diagnóstico de Enfermería en los momentos en los que la intervención enfermera ya se ha llevado a cabo (Consejo internacional de enfermeras, 1999, p. 4-5).

El propósito de la ICN es captar más la atención de la Enfermería en relación a la salud, facilitar las comparaciones entre distintos países y sus formas de Enfermería, así como promover el desarrollo de la Ciencia enfermera (Wake y Coenen, p. 112).

Ahora consideraremos los juicios diagnósticos, comenzando por preguntarnos: ¿diagnostican las enfermeras?. Es una buena cuestión en nuestra historia, ya que los juicios diagnósticos representan una parte importante y duradera, aunque agitada de ésta. Aunque Florence Nightingale diagnosticó y trató deficits nutricionales, además de otros problemas ocasionados por la Guerra de Crimea, este aspecto, dentro de sus múltiples contribuciones, no fue reconocido como parte del concepto de Enfermería profesional. Es bastante reciente cuando se ha incluido el juicio clínico dentro del currículum y prácticas de la formación y educación enfermera.

Como hemos visto hasta aquí, existieron una serie de momentos que aumentaron el interés del tema de los diagnósticos de Enfermería. Así, el proceso de Enfermería, donde se incluyen la identificación del problema de salud del paciente y el 
las diferencias entre pacientes que llegan a situaciones graves o críticas y los que no. Normalmente cuando los pacientes no logran unos resultados determinados es porque no se han empleado, ni identificado unos diagnósticos de enfermería o unos factores de riesgo. La Historia clínica informatizada del paciente supone un factor facilitante que influencia la incorporación de los diagnósticos de Enfermería dentro de la práctica clínica. Obviamente la documentación informatizada requiere de términos concisos y no de párrafos. Los diagnósticos de Enfermería comenzarán a requerirse cuando las agencias de los cuidados en salud comiencen a emplear sistemas informáticos.

\section{REFLEXIONES SOBRE EL FUTURO:}

A continuación consideraremos el futuro de los diagnósticos de Enfermería. Existe un número de factores que influenciarán los trabajos futuros que realicen la NANDA, así como otros grupos que se dediquen a la misma tarea, dentro de las naciones o regiones. Considero los siguientes 6 factores como los más importantes desde mi punto de vista:

1) Cambios en el sistema de cuidados en salud. Por ejemplo, existen diferencias o cambios en los cuidados prestados en el Hospital, en el ambulatorio y en la comunidad. Estos cambios incluyen la cirugía diaria llevada a cabo y las prontas altas a los pacientes. Sería importante estudiar los diagnósticos acontecidos en la comunidad. Por ejemplo, todavía no hemos desarrollado los diagnósticos básicos de la educación para la salud, donde se debería tener en cuenta: los conocimientos previos del paciente, la comprensión y la información sobre la salud que vamos a dar. De forma similar, no hemos encontrado todavía formas de modificar las conductas de la gente que lleven a cambios dentro de las prácticas sanitarias. ¿Se da esta situación porque realmente no hemos dado un verdadero alcance o comprensión a los problemas o factores facilitantes de los que hablábamos?.
2) Cambios demográficos en nuestras poblaciones de pacientes. En muchos países existe una población de avanzada edad. ¿Deberíamos enfocar todos nuestros esfuerzos en buscar la aplicabilidad de los diagnósticos a esta población en concreto?. ¿cuáles son las condiciones de riesgo?, ¿se han identificado?. Uno de los diagnósticos en el cual he estado trabajando es el de déficit en el sistema de soporte, desde el punto de vista afectivo e instrumental. ¿Podría ser ésta una de las razones para que exista una depresión en las personas de avanzada edad?. Los cuidados a domicilio representan una de las áreas donde más énfasis se ha hecho, debido a los cambios en la forma de llevar a cabo los cuidados y a la edad de la población. ¿Cuáles son los problemas más característicos de este tipo de población?. Se han identificado unos cuantos y de hecho, en un estudio en el cual participaron 100 enfermeras que trabajaban en la comunidad se vio que los tres diagnósticos más frecuentes que aparecían eran: déficits en el autocuidado, déficits en los conocimientos e intolerancia a la actividad. ¿Se ha desarrollado alguna línea de trabajo en este tipo de problemas?.

3) El desarrollo de la Ciencia enfermera centrando nuestro objetivo en la creación de conceptos y teorías propias. Como dijo Avant, las teorías son sólo explicaciones en nuestra mente de cómo las cosas son y funcionan. Laudan (1977) también nos da una visión del progreso científico muy interesante. Así, afirma que el mérito no es de que las teorías estén bien formuladas per se, sino de la medida de los conocimientos nuevos y del progreso en sí. Todo ello nos es útil para comprobar si estos productos de la actividad científica, contribuyen a resolver problemas relacionados con la práctica clínica. Una vez visto el objetivo que la Enfermería tiene en la sociedad y las obligaciones que se crean a partir de este objetivo, ipodemos esperar menos de la Ciencia enfermera? Las expectativas se centran en que la Ciencia enfermera pro- 
duzca nuevos conocimientos que ayuden a resolver problemas, es decir, los problemas que surgen durante el desarrollo de la práctica clínica. Esta Ciencia enfermera tiene sus pilares en los resultados de la intervención de Enfermería mediante los diagnósticos. Cada uno de estos diagnósticos deben ser observados como conceptos básicos y desarrollados como tales. El hecho de emplear conceptos específicos en los razonamientos y juicios clínicos de Enfermería difiere de la actitud que nos muestra la esencia del diagnóstico en cuanto a marcajes o clasificaciones que se extraen de listas de patologias que llevan diagnósticos asociados y que se encuentran en los libros.

Si identificamos los problemas de alta prevalencia y que tienen una alta prioridad de tratamiento, ayudaremos en la identificación de los temas prioritarios a la hora de investigar y desarrollar la Ciencia enfermera. En un proyecto que se llevó a cabo con este fin y que se basó en la información aportada por 1300 enfermeras/os que trabajaban en cuidados intensivos de adultos y neonatos, en rehabilitación y en enfermería comunitaria, se identificaron los temas o áreas con mayor prevalencia.

4) Informatización de las historias clínicas. Lo único que dará forma a la práctica enfermera en la recta final de este siglo y por supuesto, en el siguiente será la informatización de las historias clínicas. Es importante que sigamos trabajando en el desarrollo de los diagnósticos enfermeros para su incorporación en la próxima generación de ordenadores. También será importante el hecho de tener los diagnósticos desarrollados para su incorporación en la Clasificación Internacional WHO, a través del ICN (Clasificaciones Internacionales para la práctica de la Enfermería).

5) Enseñar juicios clínicos y categorías diagnósticas comunes. Las teorías apuntan a que el proceso diagnóstico general a su vez se divide en un proceso analítico (lógico) y un proceso no ana- lítico (intuitivo). El razonamiento analítico utiliza los procesos inductivos y deductivos y se suele referir a un pensamiento lógico, crítico o racional. El entendimiento aparece a partir del análisis e interpretación de la información. El razonamiento no analítico incluye la intuición y otros procesos que conllevan una inmediata comprensión de la situación. El entendimiento aparece directamente, sin necesidad de análisis, sólo a través de la intuición. El hecho de que el razonamiento analítico o no analítico predomine en el razonamiento clínico está normalmente influenciado por 3 factores: la cantidad de experiencia del diagnosticador, los requerimientos situacionales y la tarea diagnóstica en sí.

Los principiantes en la Enfermería suelen estar bastante limitados en los procesos más analíticos. Los expertos con una cierta profundidad de conocimientos en la práctica clínica pueden emplear una variedad de procesos cognitivos apropiados para cada situación y juicio clínico. Es obvio que la investigación es necesaria dentro el razonamiento y juicios clínicos de la Enfermería. Además, los esfuerzos deben dirigirse hacia la forma de educar a los nuevos enfermeros/as y en como estos estudiantes desarrollan sus habilidades a la hora de hacer juicios y razonamientos. Unido a lo dicho, también se deben desarrollar métodos de examen de las competencias en esta área. En el desarrollo de la intuición clínica, también es importante la selección de las experiencias clínicas.

6) Investigación en colaboración con enfermeras que propongan nuevos diagnósticos relacionados con sus prácticas y experiencias clínicas. La investigación obviamente completará el cuerpo de la nueva Ciencia enfermera. En particular, algunos diagnósticos necesitan ser mucho más precisos, se deben identificar poblaciones de alto riesgo, además de intervenciones y resultados unidos a sus correspondientes categorías diagnósticas. Los estudios en diferentes poblaciones determinarán: 1) 
diferencias culturales en la manifestación de una condición determinada. 2) intervenciones diagnósticas específicas que tienen en cuenta las prácticas culturales.

Todavía nos queda un camino largo por delante mientras desarrollamos nuestra Ciencia clínica, el uso de ésta y de los juicios diagnósticos y terapéuticos. Un concepto de diagnóstico no es más que una aproximación a la realidad. Si el concepto supone una aproximación útil, entonces se empleará en la práctica clínica y sobrevivirá en el "mercado de ideas". Si cambian los conocimientos, propósitos o valores de la Enfermería, entonces también cambiarán los modelos y teorías. A continuación mostraré los pensamientos de un filósofo de la Ciencia, quien incentivaba a los clasificadores a categorizar su mundo, siempre manteniéndose abierto a nuevas formulaciones, dándose cuenta de que no hay sólo una verdad o una perspectiva y especialmente evitando un aposesionamiento de las categorías (Webster, 1984). Como dijo un miembro del equipo de la ICN: "sin un lenguaje, la Enfermeria es invisible en los sistemas de cuidados en salud y su valor e importancia continuarán irreconocibles y no recompensadas. ¿Es invisible la Enfermería en nuestros paises?."

*Traducción realizada por MANUEL LILLO CRESPO.

\section{NURSING DIAGNOSIS: PAST, PRESENT, FUTURE}

The term, nursing diagnosis, refers to both a category and a process. A diagnostic category is used to describe diagnostic judgments. In the last 26 years 158 diagnostic categories have been identified by the NANDA, theNorth American Nursing Diagnosis Association, and many more are contained in the International Classification for Nursing Practice. Each of these categories has to be examined for its cultural sensitivity. The term, nursing diagnosis, also refers to the process of clinical reasoning and judgment that leads to "making" a nursing diagnosis.

In this paper I would like to discuss the Past, Present, and Future of the nursing diagnosis, as a category and as a process. There were a series of events that set the stage for the development of nursing diagnoses and a focus on nurses clinical reasoning skills

\section{PAST TO PRESENT TRANSITIONS}

I would like to suggest that nursing practice around the world has changed dramatically in the last half of the 20th century. Perhaps historians will view it as a cultural or professional revolution or at least a paradigm shift. There is one core aspect of these changes. Nurses recognize that they make clinical judgments beyond those directly associated with a disease. They act on those judgments and in the process raise the quality of health care in the country.

SLIDE 1 Transitions Nurses are developing a language to communicate judgments related to their nursing diagnosis, interventions, and outcomes. This change has emphasized the importance of nursing assessment and the kind of information that is collected for diagnosis, care planning, and evaluation. The interest in nursing-focused assessment, and particularly the functional health patterns, suggests that nurses recognize that diagnosis and treatment will not be based on valid and reliable judgments unless assessment provides valid and reliable information. Let us consider some transitions from the past that are characteristic of nursing practice in many countries.

About 25 years ago nurses began to recognize that they make important clinical judgments and that they need to identify and name the conditions that they treat. That is, name the conditions that respond best to nursing intervention. This recognition has totally changed the practice 
ofnursing in many countries. There has been a transition in the way we talk about our practice and the way we think about our practice.

\section{SLIDE-2 Past (list of three)}

SLIDE-3 Present (list of three)

Rather than rushing in with emotional support we now stop to make a differential diagnosis between fear and anxiety. Rather than saying, needs teaching, we diagnosis a knowledge deficit or a motivational problem; perhaps even a cultural conflict regarding the prescribed treatment. Some patients need teaching and some patients do not---the latter may need to deal with an underlying problem such as, denial or motivation. When a nurse judges that the patient has ineffective airway clearance, more than suctioning comes to mind. Why does the patient have this problem? Viscous (thick) secretions that require increased fluids? Ineffective coughing?

A need for assistance in bringing up secretions---through suctioning? These and other questions come to mind.

SLIDE-4 appears to be bleeding

Some in this audience will not believe this-but in the area of judgment nurses used to be taught to say----appears to be bleeding. Now we say that diagnostic, therapeutic and ethical judgment is within the nurse's professional role. Another was appears to be dead. What a transition!

The International Council of Nurses in Geneva has appointed a Task Force to develop an international classification for nursing practice. Members and echnical advisors are from Denmark, England, and the United States.

\section{SLIDE 5 ICNP}

The project is called, nursing's next advance. The Task Force is working on an international classification that will describe and classify agnoses, actions, and outcomes. After the first working paper in 1993, an alpha version of the classifica- tion system was published, and a working paper, the beta version is on the ICN web (internet) site. World Wide Web

(http://www.nethotel.dk/dihnr/Telenurse/ICNP/ beta).

The International Classification for Nursing Practice (ICNP) is not based on any conceptual framework, probably due to the theoretical pluralism that prevails in nursing in nearly all countries. (Theoretical pluralism, as you may recall, was a term used by James and Dickoff

\section{SLIDE 8 EXAMPLES}

In the 70's to describe the co-existence of many theories of nursing, such as self care agency, adaptation, life patterns, and others. Diagnoses in the ICN classification are listed under phenomena, and the remaining section is just referred to as actions. Outcomes are defined SLIDE 10 (definition-outcome)as----the status of a nursing diagnosis at points of time after a nursing intervention (International Council of Nurses, 1999,p. 4-5).

The purpose of the ICNP, and I quote from an article by two of the consultants to the Task force, is----to capture nursing's contributions to health, enable cross-country comparison of nursing practice, and promote the development of nursing science (Wake and Coenen, 1998, p. 112).

Now let us consider diagnostic judment. Do nurses diagnose? This is an important question in our history. Diagnostic judgment in nursing has a long, but choppy, history. Although Florence Nightingale diagnosed and treated nutritional deficits and other problems exhibited by the Crimean War casualties, this aspect of her many contributions was not integrated into the concept of professional nursing in its early development. It is only recently that courses on clinical judgment were included in the curriculum and integrated into clinical practice. 
There were a number of developments that led to the interest in nursing diagnosis. Nursing process, the problem identification-problem solving model of nursing care delivery, started a new phase in the profession. Yet in the 1950's and 60's the problems identified were disease-based. In the next twenty years nursing theories were published. These frameworks provided a conceptual focus for nursing process. Frameworks for practice shifted the focu s of assessment from only diseaserelated problems to a nursing focus but also included the disease, if present. In addition, nurses had gained some professional autonomy in World War II and the post-war era.

This was the social and professional context in which two faculty from St. Louis University called the First National Conference on Classification of Nursing Diagnoses in 1973. They were Mary Ann Lavin, a clinical specialist in cardiac nursing, and Kristine Gebbie. a psychiatric mental health nursing specialist. Their reasons for calling the conference were two-fold: computerization of clinical records in the University Hospital and use of nurses in ambulatory care. The purpose of the conference was to identify and classify conditions diagnosed and treated by nurses.

I had the priviledge of chairing a Task Force that was begun at this national conference. Callista Roy was a also member of this Task Force which continued until 1982 when the formal organization of NANDA, was incorporated.

Currently, classification conferences are held every two years, the 13th Conference was in Aprll, 2000 and quite a number of nurses from Spain participated. NANDA differs from other classification developers in that they see diagnostic category development, not only as a labelling of conditions, but as concept development. There is a process used for acceptance, revision, and deletion that attempts to involve as many nurses as possible--including international committee review---in which Spain participates. This is one way to attend to the cultural sensitivity of diagnoses. In addition, this year we had a submission of a new diagnosis from Spain. This was the first country outside North America to submit a diagnosis. A member of the NANDA Diagnosis Review Committee is working with this person.

What is the present status of nursing diagnosis in North America? Nursing diagnosis has been integrated to a high extent since the mid 1980's.

It is in every clinical textbook, taught in scho ols of nursing, and increasingly the subject of rese arch. It is integrated into practice in about $75 \%$ of the hospitals (that figure is based on some research in some states and personal observations). Today it has become a taken-for-granted aspect of practice. Yet, I suspect its use will decrease if attention is not given to its incorporation into recent developments in the workplace. These developments include managed care, decreased length of stay, a focus on disease outcomes in critical paths, and decreased length of stay in hospitals. Yet I doubt that we will go backwards; nursing diagnoses account for the variances, that is the differences, among patients who proceed along the critical paths and those who don't. When patients don't attain outcomes it is usually because a nursing diagnosis or risk state has not been identified. A facilitating factor that influences the incorporation of nursing diagnosis into practice is the computerized patient record. Documentation on computers requires concise terms, not paragraphs. Thus nursing diagnoses are required when a health care agency institutes a computerized information processing system.

\section{REFLECTIONS ON THE FUTURE}

Let us now consider the future of nursing diagnosis. There are a number of factors that will influence the future work of NANDA or other groups within countries or regions. These are six that I would see as important: 
1) Changes in the health care system. For example, there is a shift from hospital to ambulatory and community care. These changes include day-surgery and early discharge, It will be important to study the diagnoses that occur frequently in community settings. For example, we haven't developed the diagnoses basic to health teaching, involving the patient's knowledge, comprehension, and application of health care information. Similarly we haven't found ways to help people modify their behavior that produce lasting change in health practices. Is it because we haven't really got a grasp on the problems and facilitating factors?

2) Demographic changes in our patient populations. In most countries there is an aging population. Future efforts have to go into looking at the pplicability of our diagnostic categories for this population? What are the high risk conditions? Are they identified? One diagnsosi that I have been working on is support system deficit, both affective and instrumental. Do you think this might be one reason for depression in this older adult? Home care is another area of increased emphasis because of changes in the health care delivery system and the aging of the population. What are the patient problems characteristic of this population? We may have identified some. In a small study using 100 home health care nurses the three most frequently occurring diagnoses in their practice were self care deficits, knowledge deficit, and activity intolerance. Have we developed state of the art interventions for these conditions.?

3) Nursing Science Development with a focus on first level concepts or middle range theory. As Avant has said, theories are just explanations in our mind of how things look and work (Avant 10th). Laudan's (1977) view of scientific progress is interesting. He states that it is not the well-formulated theories, per se,--- that are the measure of new knowledge and progress. Rather, it is how well these products of scientific activity contribute to solving problems encountered in clinical practice. Given the social mandate of nursing in society--- and the obligations that come from that mandate---can we expect less from nursing science? The expectation is that nursing science will produce knowledge to solve problems--knowledge that can be used to solve the health problems encountered in practice. Valid and reliable diagnosis-intervention-outcome linkages are the building blocks of nursing science. Thus, each needs to be viewed as basic concepts and developed as such. Using concepts in clinical reasoning and judgment is very different than the attitude that says diagnosis is labelling-----that is picking problems from a book that lists the disease and associated diagnoses.

Identifying the highly prevalent conditions that are high treatment priority will aid in identifying priorities for research and development. In a project working toward this end the following areas of diagnoses were identified based on data from 1300 nurses in adult and neonatal inteñsive care, rehabilitation nursing and home care nursing. These were the diagnoses most frequently encountered and had high treatment priority. SLIDE

4) Computerization of clinical records. The one thing that will shape practice in the later part of this century and in the next is the computerization of clinical records. It will be important that we have further developed diagnoses for the next generation of computers.

It will also be important to have the diagnoses developed for incorporation into the WHO International Classification through the ICN International Classifications for Nursing Practice.

5) Teaching clinical judgment and common diagnostic categories. Current theory suggest that the diagnostic process involves analytical (logical) and non-analytical (intuitive) processes. Analytical reasoning uses inductive and deductive processes and is sometimes referred to as logical, critical, or 
rational thinking. Understanding is gained from analysis and interpretation of information.

Non-analytical reasoning includes intutition and other processes that bring an immediate comprehension of a situation. Understanding is gained directly, without analysis, through intuition. The degree to which analytic or non-analytic reasoning predominates in clinical reasoning is problably influenced by three things: the amount of experience of the diagnostician, situational requirements, and the diagnostic task.

Novices are limited to the more analytical processes. Experts with in-depth clinical knowledge and experience can use a variety of cognitive processes appropriate to the situation and the judgment task. Further reseach is needed on nurses' clinical reasoning and judgment. In addition efforts have to be directed to how we teach and/or how students develop reasoning and judgment skills. Associated with this is the need to develop methods of testing competencies in this area. In the development of clinical intuition, the selection of clinical experiences is important

6) Research in collaboration with nurses making diagnoses in their practice. Research will add to our body of nursing knowledge. In particular, some diagnoses need to be more precise, high risk populations have to be identified, and interventions and outcomes linked to diagnostic categories. Studies of different populations will determine 1) cultural differences in the anifestation of a condition and 2) diagnosis-specific interventions that take into account cultural practices.

There is much challenging work ahead as we develop our clinical science and the art of using it in our diagnostic and therapeutic judgments. A diagnostic concept is merely an approximation of reality. If the concept is a useful approximation, it will be used in clinical practice----it will "survive in the marketplace" of ideas. If nursing knowledge, purpose, or values change, the models will change. To quote a philosopher of science who urged classifiers to categorize their world but to maintain an "openness to new formulations, realizing that there is not just one truth or one perspective, and especially avoiding "hardening of the categories"(Webster,1984). As has been said in the ICN Task Force: As one member of the ICN Task Force has said----Without a language, nursing is invisible in health care systems and its value and importance go unrecognized and unrewarded.Is nursing invisible in our countries?

Thank you for the invitation to your conference, Culture in Caring, on June 15-18, 2000. I will be pleased to talk on the subject you suggested, Nursing Diagnosis: Past, Present, and Future. Are there any aspects that you wish to have emphasized? In order to determine the correct level of presentation, may I ask if nurses are beginning to use nursing diagnosis in education and ractice. Or, shall I emphasize the importance of diagnosis and diagnostic reasoning?

I will arrive in Alicante from Frankfurt on Condor Airlines \# 2422 at 8am.on June 13 and will plan to leave on the 20th so there is a day or so to see your city. As Dr. Spector may have told you I am scheduled to speak in Ljublja, Slovenia. I will be there from early June until I come to Alicante.

The transatlantic portion of the airline ticket will be split between Alicante and Slovenia.

Dr. Spector mentioned that you will be paying transportation, room, andboard during the conference days. Will there be an honorarium?

Are slides or overheads better for your auditorium? I will be sending the paper in the next few weeks. Also, I would like to have some handouts that will update diagnosis development after the April, North American, Biennial Conference in Orlando. Any information that you can share with me to make the presentation meetyour needs will be appreciated.

Looking forward to the conference. Could you just reply with a YES so that I know you received this. 